\title{
Da taxa média de lucro industrial à taxa média de lucro geral e ao lucro bancário - uma formalização com base em Marx
}

From the industrial average rate of profit to the general average rate of profit and bank profit - a formalization based on Marx

Claus M. Germer ${ }^{a}$

\begin{abstract}
Resumo: O presente artigo tem como principal objetivo expor e formalizar a concepção completa da taxa média de lucro de Marx. Pontos não esclarecidos permanecem e serão apontados, podendo servir como desafios para a extensão desta pesquisa. Neste artigo aborda-se principalmente o aspecto quantitativo do desenvolvimento da taxa média de lucro, concedendo-se menos espaço para a análise dos pontos teóricos relevantes. O segundo objetivo, complementar ao primeiro, é propor uma formalização do capital e do lucro bancários, compatíveis com a verdadeira taxa média de lucro, a esta altura já exposta. Este objetivo é necessário a fim de fornecer um enfoque abrangente da verdadeira taxa média de lucro e de suas consequências sobre todas as formas do capital.
\end{abstract}

Palavras-chave: Taxa Média de Lucro; Economia Marxista; Lucro Bancário Classificação JEL: B14, E11, P16

\begin{abstract}
The main objective of this paper is to expose and formalize Marx's complete conception of the average rate of profit. Unclarified points remain and will be pointed out, which could serve as challenges for the extension of this research. In this paper it is mainly addressed the quantitative aspect of the development of the average rate of profit, giving less space to the analysis of the relevant theoretical points. The second objective, complementary to the first one, is to propose a formalization of bank capital and profit, compatible with the true average rate of profit, at this point already exposed. This objective is necessary in order to provide a comprehensive approach to the true average rate of profit and its consequences for all forms of capital.
\end{abstract}

Keywords: Average Profit Rate; Marxist Economics; Bank Profit

JEL Classification: B14, E11, P16

\footnotetext{
a Professor Associado IV Aposentado do Departamento de Economia da Universidade Federal do Paraná (DEPECON/UFPR). Email: $\underline{\mathrm{cmg} 402.501 @ \text { gmail.com. }}$
} 


\section{Introdução}

O interesse pela taxa média de lucro, no debate marxista, tende a concentrar-se nos problemas propostos pela lei da tendência de queda da mesma. Menos interesse tem sido dedicado aos problemas da natureza teórica do próprio conceito e da sua determinação. $\mathrm{O}$ resultado é que, frequentemente, o debate sobre a lei da tendência - cujos autores supõem estarem referindo-se à verdadeira taxa média de lucro, gira na realidade em torno de um conceito incompleto da mesma ${ }^{1}$, exposta na seção II d'OCIII ${ }^{2}$. Isto deve-se talvez ao fato de que o debate sobre a lei da tendência em si detém-se na seção III, capítulos 13 a 15, que focalizam o tema, ao passo que a exposição da forma definitiva [ou acabada - fertige, no original em alemão (MARX, 1980a p. 319)] da taxa média, por Marx, só se completa na quarta seção, dedicada ao capital mercantil ${ }^{3}$, mas ainda repercute na seção V. Mas o pleno entendimento dos problemas da definição final de Marx requerem que a pesquisa se estenda até a quinta seção, dedicada ao capital portador de juros ou capital de empréstimo.

Todavia, embora Marx seja explícito (embora pouco enfático) em afirmar o caráter incompleto da versão da taxa média de lucro exposta na seção II, e a complemente na IV, subsiste um ponto não muito claro no seu tratamento da questão, que consiste na forma, e nas implicações, da transferência de mais-valia do capital industrial ao capital de comércio de dinheiro, e no motivo de rejeitar a participação deste na formação da taxa média de lucro. A tentativa de esclarecimento deste problema, feita neste artigo, requer a incursão na quinta seção d'OCIII, detendo-se especificamente na análise da estrutura do capital bancário e da determinação das dimensões e da taxa de lucro deste capital, de modo a tornálas compatíveis com o conceito da verdadeira, ou definitiva, taxa média de lucro.

$\mathrm{O}$ conceito de capital bancário, que se exporá, pretende também sugerir uma formalização dos conceitos dele derivados, tal como expostos por Marx. Neste aspecto, o artigo procura inovar ao propor uma sistematização de conceitos capaz de servir de base a uma mais adequada quantificação, apoiada na teoria de Marx, dos elementos da estrutura do capital bancário atualmente.

O presente artigo tem como principal objetivo expor e formalizar a concepção completa da taxa média de lucro de Marx. O tema é complexo e não pode ser esgotado em um artigo. Pontos não esclarecidos permanecem e serão apontados, podendo servir como desafios para a extensão desta pesquisa. Neste artigo aborda-se principalmente, porém, o aspecto quantitativo do desenvolvimento da taxa média de lucro, concedendo-se menos espaço para a análise dos pontos teóricos relevantes.

\footnotetext{
${ }^{1}$ Autores como Moseley (1991), que realiza uma exaustiva análise da queda da taxa média de lucro nos EUA no pós-IIGM, fazem exceção a esta prática.

${ }^{2}$ Dada a quantidade de citações de $O$ Capital, de Marx, as referências à obra utilizam apenas as suas iniciais OC, seguidas do volume em romanos e do tomo em arábicos.
}

${ }^{3}$ Neste artigo denomina-se capital mercantil o conjunto dos capitais de comércio de mercadorias e de dinheiro. 
O segundo objetivo, complementar ao primeiro, é propor uma formalização do capital e do lucro bancários, compatíveis com a verdadeira taxa média de lucro. Este objetivo é necessário a fim de fornecer um enfoque abrangente desta última e de suas consequências sobre todas as formas do capital.

$\mathrm{O}$ artigo divide-se em três seções, além da introdução. A primeira analisa a influência, sobre a formação da taxa média de lucro, da rotação do capital; a segunda, a mais extensa, focaliza a influência do capital mercantil, decompondo-se em duas subseções, nas quais se analisa as influências dos capitais comercial e bancário, respectivamente. A análise do capital bancário, por sua vez, apresenta as concepções de Marx sobre a estrutura deste capital e decompõe-se nas análises dos seus dois segmentos, os capitais de comércio de dinheiro e de crédito, respectivamente. A última subseção, finalmente, expõe as determinações teóricas das dimensões do capital e do lucro bancários. Segue-se, por último, uma síntese das principais conclusões.

O artigo não é de verificação empírica, mas de formalização de aspectos relevantes das teorias da taxa média de lucro e bancária de Marx.

\section{A Elaboração Teórica da Taxa Média de Lucro}

A exposição da transformação da mais-valia em lucro decompõe-se em níveis progressivos de análise, expostos nas primeiras três seções de OCIII/1 e sumariadas por Marx (OCIII/1, p. 130):

i) a conversão da mais-valia em lucro, restrita ao aspecto conceitual, sem, portanto, afetar o seu valor;

ii) conversão da taxa de mais-valia, massa de mais-valia $(m)$ dividido pelo capital variável $(v)$, ou $\frac{m}{v}$, em taxa de lucro, através do acréscimo do capital constante $(c)$ ao denominador da fórmula da taxa de mais-valia $\left\{\frac{m}{(c+v)}\right\}$, que acrescenta ao aspecto conceitual um componente quantitativo apenas formal, não afetando a massa da mais-valia expressa no lucro;

iii) conversão da taxa de lucro em taxa média de lucro - restrita ao capital industrial, que incorpora ao aspecto quantitativo formal também o quantitativo material, alterando quantitativamente as massas de mais-valia representadas pelos lucros setoriais;

iv) finalmente, a tendência de queda da taxa média de lucro. 
São patamares diferentes da explicação teórica, cada uma envolvendo fatores e implicações próprios. Estes podem ser apresentados nos seguintes elementos:

(i)

(ii)

(iii)

A conversão da mais-valia em lucro é, em primeiro lugar, uma projeção ideológica da prática real da economia capitalista, segundo a visão dos proprietários do capital, isto é, molda o pensamento segundo o modo como a superfície da realidade é percebida por estes (cap. 1 do OCIII/1). É uma projeção que oculta e distorce a realidade, mas altera a natureza da mais-valia apenas conceitualmente, não numericamente, ao conceber a mais-valia como fruto não do capital variável, mas do capital total.

A conversão da taxa de mais-valia em taxa de lucro aprofunda a distorção e o mascaramento, ao expressar o conceito numericamente, relacionando $m$ a $c+v$, ao invés de apenas a $v$, mas não altera o valor de $m$ (cap. 2 e 3 de OCIII/1). Nestes dois passos a análise limita-se à lógica interna do capital produtivo, que é o capital industrial ${ }^{4}$, como abstração da essência dos capitais industriais setoriais, o 'capital em geral'. Marx segue, neste caso, o seu critério de abordar os temas de estudo em primeiro lugar abstratamente ${ }^{5}$.

Já a análise da conversão da taxa de lucro em taxa média de lucro requer a consideração do capital industrial global, decomposto nos seus grandes ramos e respectivas subdivisões. Pela forma da exposição, a análise deste tema parece esgotar-se nos cap. 8 e 9 de OCIII/1, motivo pelo qual pode-se não perceber que a determinação da taxa média de lucro não se completa aqui, e o próprio Marx só o esclarece bem à frente. A análise da lei da tendência de queda da taxa média de lucro, que se segue (cap. 13-15, OCIII/1), também não é precedida de uma advertência, por Marx, de que se trata não da verdadeira taxa média de lucro, isto é, da taxa realmente operante na economia, mas apenas da taxa média de lucro restrita ao capital industrial. Sendo assim, a denominação mais precisa desta taxa, adotada neste artigo, seria taxa média de lucro industrial $\left(\overline{l_{i}^{\prime}}\right)$. O que falta, porém, é considerar a influência da rotação do capital, analisada na seção seguinte. Isto é consistente, uma vez que se trata da medida da mais-valia com referência ao capital que a produz, que é o capital

${ }^{4}$ Os fundamentos destas formulações já se encontram bem desenvolvidos nos Manuscritos de 1861/63 (MEGA II/3.5, p.1598-1632), exemplo do que Marx denominou 'método de pesquisa', a ser focalizado mais adiante.

${ }^{5}$ Ao analisar a transformação do dinheiro em capital, Marx aponta o sentido da necessidade da abstração, ou seja, "considera[r] abstratamente, isto é, [não considerar] as circunstâncias que não decorrem das leis imanentes [do fenômeno analisado] ..." (OCI,p. 132, acréscimos próprios). Ou seja, é necessário "abstrair essa[s] circunstância[s] como sendo casua[is], para ter pela frente, em sua pureza, o fenômeno [analisado] [...] e não ser confundido em sua observação por circunstâncias secundárias, perturbadoras e estranhas ao verdadeiro decurso" (Ibidem, p. 138; ver também Marx, 1980b, p. 233, acréscimos próprios). 
industrial. Correspondentemente, a taxa média de lucro, que Marx denomina definitiva, por incorporar todos os seus determinantes, será denominada taxa média de lucro geral $\left(\overline{l_{g}^{\prime}}\right)^{6}$, com o que se elimina a confusão entre as duas taxas.

Os fatores que determinam a geração de mais-valia e da taxa de mais-valia, assim como sua conversão em lucro industrial $\left(l_{i}\right)$ e taxa média de lucro industrial $\left(\overline{l_{i}^{\prime}}\right)$, respectivamente, são fatores que atuam sobre o capital industrial, abstraídas as demais formas do capital. Já os fatores que determinam a formação da taxa média de lucro geral $\overline{l_{g}^{\prime}}$ não se restringem ao capital industrial, mas incluem o capital mercantil. Os primeiros são identificados antes da introdução do capital comercial na exposição. Os principais fatores determinantes da taxa média de lucro industrial, restritos, portanto, ao capital industrial, são aqueles que determinam diferenças nas características técnicas dos capitais aplicados nas diversas esferas industriais. São eles a composição orgânica, a rotação e a distribuição entre os diversos ramos industriais, destacando-se apenas a composição orgânica ${ }^{7}$.

Marx detém-se a considerar explicitamente, por exemplo, como fatores, no capítulo 9, a composição orgânica e a distribuição do capital entre os ramos industriais, e expõe esta última com destaque (OCIII/1, p. 126-7). A influência da rotação sobre a taxa média de lucro é remetida a abordagem posterior, o que, no entanto, não ocorreu. Mesmo o capítulo 4 do OCIII/1, sobre a rotação, acrescentado por Engels, aborda apenas o seu efeito matemático, mas não a sua natureza e particularidades, o que, no entanto, foi extensamente analisado por Marx no OCII.

\footnotetext{
${ }^{6}$ Não confundir a taxa média de lucro geral com a taxa geral de lucro, que Marx também utiliza para referir-se à taxa média de lucro, em que, portanto, o termo geral é utilizado como sinônimo de média (OCIII/1, cap. 9, título; explicitamente p. 255). Na expressão taxa média de lucro geral, o termo geral distingue esta taxa da que se refere apenas ao capital industrial que, por oposição, deveria ser lida como taxa média de lucro industrial.

${ }^{7}$ Há fundamento para se atribuir a exclusão da taxa de mais-valia, por Marx, ao pressuposto da taxa de maisvalia uniforme na economia, por depender de dois elementos também uniformes: a extensão da jornada de trabalho e o valor da força de trabalho. Teoricamente, deve-se admitir que os mercados das mercadorias tendem a uniformizar-se, o que implica a uniformização dos seus valores de uso e preços. No caso da força de trabalho, também uma mercadoria, a análise abstrata implica que seus valor de uso (extensão da jornada) e preço (salário), expressão do seu custo de reprodução ou valor, tendem à uniformização, com ajustes para mais ou para menos em função de particularidades regionais ou de outro tipo, excluídos na análise abstrata.
} 


\section{A Taxa Média de Lucro Industrial e a Rotação do Capital}

Marx expõe a natureza essencial da taxa média de lucro industrial $\left(\overline{l_{i}^{\prime}}\right)$ e o processo da sua formação na seção II do OCIII ${ }^{8}$, intitulada "A transformação do lucro [industrial] em lucro médio [industrial]", e a complementa nas seções 4 e 5. Na sua primeira versão, na seção II, a fórmula da taxa média de lucro industrial é:

$$
\bar{l}^{\prime}=\frac{m}{\mathrm{C}}
$$

em que $m$ é a massa anual de mais-valia e $C$ o capital investido $c+v$, ambos em termos agregados de toda a economia (OCIII/1, p. 34, 39). Deve-se notar que, do início do OCI até o capítulo 8 do OCIII/1 analisa-se os valores das mercadorias e o processo da sua formação. Isso implica que a análise se refere ao capital industrial, uma vez que é este o responsável, no capitalismo, pela produção das mercadorias e seus valores. O capital mercantil (compreendendo os capitais comercial e bancário) está, até este ponto, excluído da análise, uma vez que só pode ser analisado adequadamente após a formação da taxa média de lucro industrial. No capítulo 9 do OCIII/1, introduz-se os preços de produção, resultantes da formação da taxa média de lucro industrial.

Marx analisa esta, neste capítulo e na exposição subsequente, exclusivamente em sua relação com a composição orgânica do capital, e assim continuam os autores subsequentes a proceder em muitos casos. No entanto, nos mesmos capítulos 8 e 9, Marx chama a atenção para o fato de que as taxas de lucro setoriais, assim como a taxa média de lucro industrial, dependem não só da composição orgânica do capital de cada setor, mas também do tempo de rotação ${ }^{9}$, e, no capítulo 9 , como já mencionado, dá destaque à distribuição setorial do capital industrial. Tanto a composição orgânica quanto o tempo de rotação são entendidos, neste caso, como médias setoriais.

Se os tempos de rotação dos capitais industriais setoriais afetam as massas de mais-valia por eles produzidas, é óbvio que afetarão também a taxa média de lucro industrial,

\footnotetext{
8 Todavia, a gênese do conceito inicia-se nos Grundrisse, e prossegue nas Teorias da Mais-valia e nos Manuscritos econômicos de 1861-63, desembocando finalmente nos manuscritos utilizados por Friedrich Engels para compor o OCIII.

9 “[...] as taxas de lucro de diversas esferas da produção, existentes simultaneamente uma ao lado da outra, serão diferentes se, com as demais circunstâncias constantes, os períodos de rotação dos capitais empregados forem diferentes ou se a relação de valor entre os componentes orgânicos desses capitais [isto é, a composição orgânica do capital - cmg], nas diversas esferas da produção, for diferente. (...). Por conseguinte, teremos de investigar: 1) as diferenças na composição orgânica dos capitais; 2) as diferenças em seus períodos de rotação" (OCIII/1, p. 112). No início do cap. 9 anuncia-se que, apesar da sua influência sobre a taxa de lucro industrial, as diferenças de tempos de rotação seriam abstraídas (Ibidem, p. 121), e que este ponto seria analisado adiante, o que, entretanto, não ocorreu. Já no cap. 3, Marx advertira que a rotação seria, por ora, abstraída, uma vez que "a sua influência sobre a taxa de lucro seria analisada especialmente em um capítulo posterior" (OCIII/1, p. 40). Como Marx não chegou a redigir este capítulo, Friedrich Engels o fez e o inseriu neste volume da obra, como cap. 4.
} 
fenômeno que necessita, portanto, ser formalizado. $\mathrm{O}$ fato de haver tempos de rotação diferentes nos diferentes setores industriais, implica que se deve conceituar um tempo de rotação médio do capital industrial global. A influência formal do tempo de rotação dos capitais individuais e do tempo médio de rotação do capital global sobre a massa de maisvalia produzida não é difícil de estabelecer, uma vez que os conceitos básicos para tanto a mais-valia anual $\left(m_{a}\right)$ e a taxa anual de mais-valia $\left(m_{a}^{\prime}\right)$ - foram desenvolvidos e expostos por Marx no cap. 16 do OCII, com as seguintes fórmulas:

$$
\begin{array}{lll}
m_{a}^{\prime}=n \cdot m^{\prime}, & \text { ou } & m_{a}^{\prime}=n \frac{m}{v}, \\
m_{a}=n \cdot m, & \text { ou } & m_{a}=n \cdot m^{\prime} v=m_{a}^{\prime} \cdot v
\end{array}
$$

em que $n$ é o número de rotações do capital variável por ano ${ }^{10} \mathrm{e} m$ e $m$ ' são a mais-valia e a taxa de mais-valia reais, isto é, correspondentes a uma rotação do capital variável (OCII, p. 227-8 $)^{11}$. No cap. 4, Engels explicitou, com base nestes conceitos, a consequência óbvia de que a mais-valia a ser utilizada no cálculo da taxa de lucro de um capital industrial individual, assim como do capital industrial global, é a mais-valia anual e não a mais-valia real. Neste caso a fórmula correta da taxa de lucro $^{12}$ de um capital passa a ser (OCIII/1, p. 58):

$$
l^{\prime}=\frac{m_{a}}{C} \quad \text { ou } \quad l^{\prime}=\frac{n \cdot m}{C}
$$

em que C maiúsculo, no denominador, é o capital total adiantado.

Supondo que os capitais pertencentes a diferentes ramos industriais tenham a mesma composição orgânica, os mesmos obterão diferentes taxas de lucro caso possuam diferentes tempos de rotação dos seus capitais variáveis ou, alternativamente, poderão obter as mesmas taxas de lucro, mesmo tendo diferentes composições orgânicas, caso possuam tempos de rotação diferentes e que compensem as diferenças de composições orgânicas. Disto pode-se concluir que, se a elevação da composição orgânica for compensada por uma

\footnotetext{
${ }^{10}$ Todas as menções à rotação do capital, neste artigo, referem-se exclusivamente à rotação do capital variável, mesmo quando isto não esteja especificado. $\mathrm{O}$ mesmo aplica-se às citações de Marx, uma vez que ele analisa a taxa média de lucro com exemplos numéricos nos quais todo o capital é circulante, caso no qual as rotações do capital variável e do capital total coincidem. A exclusividade do capital variável, na análise do tema deste artigo, decorre do fato de ser o capital variável o gerador de mais-valia, em nada sendo afetado pelas características de magnitude e rotação do capital constante.

${ }^{11}$ As notações utilizadas por Marx, no capítulo 16 d'OCII ( $M V^{\prime}$ para a taxa anual de mais-valia, $m v^{\prime}$ para a taxa de mais-valia real, e $c v$ para capital variável) diferem e são mais confusas que as utilizadas no OCI e no OCIII, que são as adotadas neste artigo. Inova-se apenas ao acrescentar o subscrito $a$ para identificar a mais-valia e a taxa de mais-valia anuais.

${ }^{12}$ Engels refere-se a esta taxa como taxa de lucro anual, mas isto é rigorosamente desnecessário, uma vez que a taxa de lucro é inequivocamente uma medida da rentabilidade anual dos capitais (MARX, 1992, p. 7-8).
} 
elevação do número de rotações, ou vice-versa, a taxa média de lucro não se alterará, ou se alterará conforme a proporção desta compensação. Já por aí se percebe a relevância da incorporação explícita da rotação do capital à análise da taxa média de lucro industrial e de sua evolução.

Como Marx só analisou a formação da taxa média de lucro industrial como função da variação da composição orgânica do capital, as ilustrações numéricas da sua exposição foram construídas com base nos pressupostos simplificadores de que, primeiramente, todos os capitais realizavam apenas uma rotação anual, e, segundo, a taxa de mais-valia real era de $100 \%$, condição para que as mais-valias produzidas por todos os setores fossem iguais aos capitais variáveis adiantados. Assim, a fórmula do valor do produto de cada setor era:

$$
C^{\prime}=c+v+m
$$

em que $C^{\prime}$ representa o capital realizado ou acrescido de mais-valia, ou seja, representa o produto anual de cada capital. No entanto, ao se analisar a influência das diferenças de rotação por setor, o que se pressupõe constante é a composição orgânica do capital. Neste caso os produtos setoriais anuais serão diferentes e o produto anual de cada um será representado pela fórmula

$$
C^{\prime}{ }_{i}=n_{i}\left(c_{i}+v_{i}\right)+n_{i} m_{i} \quad \text { ou } \quad C^{\prime}{ }_{i}=n_{i}\left(c_{i}+v_{i}\right)+m_{i}^{a}{ }^{13}
$$

em que o subscrito $i$ designa os setores da economia.

Consequentemente, a taxa média de lucro industrial não pode ser simplesmente $\frac{\mathrm{m}}{\mathrm{C}}$, caso se deseje estudar os efeitos da rotação do capital variável. Para a exposição que se segue é conveniente reescrever a fórmula (1), a fim de explicitar o fato de que tanto $m$ quanto $C$ constituem os somatórios ou valores agregados das mais-valias e dos capitais industriais investidos de toda a economia ${ }^{14}$, respectivamente:

\footnotetext{
${ }^{13}$ Embora as características do capital constante não afetem o tema em análise, é conveniente explicitar o fato de que ' $c$ ', na fórmula de $C$ ', não consiste no capital constante investido, mas no consumido. Havendo capital fixo, este decompõe-se em $d_{f}$ e $c_{c}$, ou seja, depreciação do capital fixo e capital constante circulante, respectivamente. Introduzindo-os na fórmula de $C^{\prime}$, esta teria a forma $C^{\prime}=n\left\{\left(d_{f}+c_{c}\right)+v+m\right\}$, que representa o fato óbvio de que todo o capital consumido em cada rotação se multiplica pelo número de rotações anuais a fim de expressar o consumo anual de capital. Como o interesse, aqui, é destacar a multiplicação da mais-valia, é preferível utilizar a fórmula $C^{\prime}=n\left\{\left(d_{f}+c_{c}\right)+v\right\}+m_{a}$. Lembrar também que o que varia com a variação da rotação é o capital consumido, enquanto o capital investido $C$ permanece inalterado, considerando que o capital fixo total se divide em duas partes, sendo uma a fração consumida e reposta em dinheiro, e a outra a fração ainda não consumida.

${ }^{14}$ A fim de facilitar a leitura não se acrescenta ao símbolo da soma $(\Sigma)$ a indicação da variação de $i$, uma vez que esta está suficientemente clara no texto.
} 


$$
\bar{l}^{\prime}=\frac{\sum m_{i}}{\sum \mathrm{C}_{i}}, \text { com } \mathrm{C}_{i} \text { maiúsculo }
$$

O mesmo aplica-se à fórmula quando nela se introduzem as diferentes rotações dos capitais variáveis setoriais, que decorrem dos diferenciais de tempos de rotação por setor:

$$
\bar{l}^{\prime}=\frac{\sum n_{i} m_{i}}{\sum \mathrm{C}_{i}} \quad \text { ou } \quad \bar{l}^{\prime}=\frac{\sum m_{i}^{a}}{\sum \mathrm{C}_{i}} \quad \text { (3), com } \mathrm{C}_{i} \text { maiúsculos }
$$

em que $n_{i}$ representa os diferentes números de rotações anuais dos $z$ setores da economia e $m_{i}^{a}$ as mais-valias anuais dos mesmos.

Esta fórmula expressa o fato de que a taxa média de lucro industrial é afetada pelos tempos de rotação dos capitais setoriais: quanto maior o número de rotações dos capitais variáveis setoriais, maiores serão a massa total de mais-valia e a taxa média de lucro, e vice-versa.

Das diferenças dos números de rotações setoriais deve-se derivar o número médio de rotações do capital variável industrial global, que corresponderá à média das rotações setoriais ponderadas pelas participações dos capitais variáveis setoriais no capital variável total:

$$
\bar{n}_{p}=\sum n_{i} \frac{v_{i}}{\sum v_{i}}
$$

em que $\bar{n}_{p}$ é a média ponderada das rotações dos capitais variáveis setoriais (Passarella \& Baron, 1913). fórmula:

Como $m=m$ 'v, segue-se que a mais-valia total da economia será dada pela seguinte

$$
\sum m=\bar{n}_{p} \sum v_{i} m^{\prime}
$$

No entanto, $m$ ' tende a ser uniforme na economia por ser uma característica estrutural da mesma, como já justificado ${ }^{15}$, a forma final da mais-valia total seria:

$$
\sum m=\bar{n}_{p} m^{\prime} \sum v_{i}
$$

Substituindo (4) em (1) obtém-se

$$
\bar{l}^{\prime}=\frac{\bar{n}_{p} m^{\prime} \sum v_{i}}{\sum \mathrm{C}_{i}} \quad \text { (5), com } \mathrm{C}_{i} \text { maiúsculo }
$$

\footnotetext{
${ }^{15}$ Ao se focalizar, porém, a taxa média de lucro geral, o estudo da sua evolução no tempo ou entre países requer a consideração da taxa de mais-valia, cuja variação nestas dimensões possui, como é óbvio, efeitos significativos.
} 
fórmula esta que coloca em evidência a influência do número médio de rotações do capital variável total sobre a taxa média de lucro industrial: quanto maior o número médio de rotações anuais - ou seja, quanto menor o tempo médio de rotação, maior será a taxa média de lucro, e vice-versa.

A fórmula (5) permite concluir que, havendo uma tendência contínua determinada de $\bar{n}_{p}$ ao longo do tempo, ela afetará a trajetória de tendência da taxa média de lucro industrial. Caso haja, por exemplo, uma tendência continuada de aumento do tempo médio de rotação do capital variável total, $\bar{n}_{p}$ se reduzirá, causando redução da taxa média de lucro e vice-versa. Não se encontrou fontes marxistas que tenham analisado a evolução histórica da rotação do capital variável e seus determinantes. Assim, parece ser pouco o que se conhece, sobre a tendência de um dos dois determinantes fundamentais da taxa média de lucro. Enquanto a composição orgânica do capital é bem conhecida e utilizada pelos autores marxistas, muito menos avanço se fez sobre o comportamento da rotação do capital, a despeito da inegável relevância deste fator.

Da fórmula geral da taxa média de lucro industrial (1), Sweezy (1976), por exemplo, derivou uma fórmula em que a taxa média de lucro "é uma função da taxa de mais-valia e da composição orgânica do capital", que são, segundo ele, as "variáveis primárias' das quais se deve considerar que depende a taxa de lucro industrial 'na análise teórica' (SWEEZY, 1976, p. 97):

$$
\overline{l^{\prime}}=m^{\prime}\left(1-q_{o}\right)
$$

em que $q_{o}$ é a composição orgânica do capital. É curioso que, embora conhecedor do tratamento dado por Marx ao problema da rotação dos capitais, e citando-o explicitamente, Sweezy a exclua do cálculo da taxa média de lucro industrial, sob o argumento de 'focalizar ... atenção sobre os elementos essenciais da teoria', aparentemente ignorando o caráter essencial da rotação para a taxa de lucro na concepção de Marx. No entanto, a rotação pode ser incluída facilmente na fórmula de Sweezy, bastando introduzir a rotação média do capital variável global como multiplicador de $m$ ', que daria a taxa de mais-valia anual média, e explicitando que a $\bar{q}_{o}$ também é a média ponderada das composições orgânicas setoriais:

$$
\overline{l^{\prime}}=\bar{n}_{p} m^{\prime}\left(1-\bar{q}_{o}\right)
$$

\section{A Taxa Média de Lucro e o Capital Mercantil}

Ao focalizar o papel do capital mercantil é necessário iniciar com uma consideração sobre a terminologia utilizada por Marx para designar as diversas categorias analíticas relevantes, pois a terminologia não é uniforme, com títulos diferentes para uma mesma categoria ou um mesmo título para categorias diferentes, o que pode confundir o 
leitor e dificulta a leitura. A seguir, se indicará uma terminologia um pouco mais uniforme, utilizada neste artigo, a fim de facilitar a exposição do tema e o entendimento dos leitores, sem afetar em nada seus significados teóricos.

As edições d'O Capital, da Abril e da Boitempo utilizam a expressão capital comercial como tradução de kaufmännisches Kapital (um dos sinônimos de capital comercial) utilizado por Marx como título da seção IV, referindo-se ao conjunto dos capitais de comércio de mercadorias e de comércio de dinheiro (OCIII/1, p. 201), mas no capítulo 17, Marx utiliza kommerzielle tanto no título (Der kommerzielle Profit - O lucro comercial) quanto em todo o texto ${ }^{16}$, o que não ocorre nos demais capítulos, quando outros sinônimos são utilizados ${ }^{17}$, diferindo a variação segundo o capítulo. Para melhor distinção, neste artigo se denominará capital mercantil ao conjunto dos dois capitais, como já mencionado, reservando o título de capital comercial, tal como Marx o faz também com frequência, apenas para o capital de comércio de mercadorias. Por outro lado, com o título de capital de comércio de dinheiro Marx designa um capital (atualmente representado pelos bancos comerciais) que realiza duas funções, inseparáveis, mas qualitativamente diferentes, o comércio de dinheiro propriamente dito e o comércio de crédito (Ib., p. 240), sendo este último, segundo Marx, o mais importante (II/3.5, p. 1701), de modo que o título confunde uma só função - a menos relevante - com o capital que realiza ambas. Isto significa que a empresa bancária administra dois capitais, um dedicado ao comércio de dinheiro e o outro ao comércio de crédito. No entanto, isto não é exposto de modo inequívoco, podendo se constituir como outra fonte de confusão ao leitor. Por este motivo utiliza-se, neste artigo, o título de capital bancário, no lugar de capital de comércio de dinheiro, para designar o capital que realiza as duas funções, reservando o título de capital de comércio de dinheiro apenas para a parte do capital bancário aplicada especificamente no comércio de dinheiro, e de capital de comércio de crédito a parte dedicada a este.

Além disso, o comércio de dinheiro e o capital de comércio de dinheiro são o tema da seção IV, sob o título geral de capital comercial, enquanto o comércio de crédito, que é o comércio do capital portador de juros, é analisado sob este último título na seção V. Porém, o vínculo do capital portador de juros com o capital de comércio de dinheiro não é adequadamente esclarecido, e a expressão capital de comércio de dinheiro praticamente desaparece, exceto por duas breves menções em dois capítulos distantes do início da seção

\footnotetext{
${ }^{16}$ As traduções brasileiras d'OCIII tiveram dificuldade em ser fieis ao original, pois Marx utiliza diversos sinônimos para referir-se ao capital de comércio de mercadorias (Warenhandlungskapital; kaufmännisches Kapital; Kaufmannskapital; Handelskapital; kommerziellen Kapital). Em relação apenas aos títulos da seção IV e dos quatro capítulos que a compõem, Marx utilizou quatro sinônimos diferentes, enquanto as traduções da Abril e da Boitempo adotaram, mais criteriosamente, somente duas expressões - capital de comércio de mercadorias e capital comercial, mas utilizaram esta última expressão tanto para o capital de comércio de mercadorias como para o conjunto dos capitais de comércio de mercadorias e de dinheiro, o que pode confundir o leitor.
}

${ }^{17}$ Esta diferença, muito evidente, pode indicar uma particularidade talvez teórica, na língua alemã, o que, porém, não pôde ser esclarecido. 
V (OCIII/1, pp. 293 e 303). As diferenças de terminologia da seção V em relação à seção IV sugerem que Marx as elaborou em momentos diferentes, o que, no entanto, não foi esclarecido.

Esta desuniformidade de títulos das categorias principais é um dos obstáculos ao correto entendimento das opiniões - e do grau do seu desenvolvimento - de Marx sobre a estrutura do capital mercantil, que compreende - é preciso lembrar ${ }^{18}$ - não só o capital comercial, mas também o capital portador de juros d'OCIII.

O tema que ocupa a maior parte do OCIII é a distribuição da mais-valia, que tem como pressuposto a formação da taxa média de lucro industrial e dos correspondentes preços de produção. Como os capitais industriais obtêm o lucro médio e não a mais-valia produzida, a distribuição da mais-valia apresenta-se, em parte, na formação e em parte, na distribuição do lucro médio. Como a mais-valia e o lucro médio dela derivado são gerados pelo capital industrial, segue-se que a distribuição da mais-valia implica a distribuição de frações do lucro médio, obtido pelo capital industrial, a segmentos da classe capitalista que desempenham as funções do capital industrial na circulação - os capitais comercial e bancário - e a outros integrantes da sociedade capitalista, de natureza diversa do capital propriamente dito - os proprietários de terra e o Estado. Destes, Marx só não analisa, no OCIII, a fração destinada ao Estado ${ }^{19}$.

Segundo Marx, o capital mercantil divide-se em dois segmentos: capital comercial, que realiza a comercialização das mercadorias, e o capital bancário, uma de cujas funções é o comércio de dinheiro, isto é, a realização das operações meramente técnicas exigidas pelas operações monetárias originadas na circulação do dinheiro, por sua vez causada pela circulação das mercadorias ${ }^{20}$, sendo a outra função a de comércio de crédito, que é o comércio de capital portador de juros.

As frações da mais-valia obtidas pelos seus diferentes beneficiários possuem

\footnotetext{
${ }^{18}$ Este lembrete se justifica porque, na maior parte dos casos, os leitores d'OCIII não percebem que o capital portador de juros é uma categoria pertencente ao capital mercantil, uma vez que consiste em uma atividade comercial, o comércio de crédito, emanada do desenvolvimento da fase M'-D', ou de circulação, do capital industrial. O banco comercial moderno é, talvez, o ente que melhor representa a categoria do capital bancário, uma vez que combina as suas duas funções.
}

${ }^{19}$ Uma contribuição ao entendimento do processo de transferência da mais-valia para o Estado pode ser encontrada em (GERMER, 2009).

${ }^{20}$ Esta forma de exposição parece redundante, mas expressa rigorosamente o caráter meramente técnico expressão repetida diversas vezes por Marx - das ações realizadas pelo capital bancário, o banco. Marx, coerentemente com a concepção materialista da primazia da produção, concebe a circulação monetária como passiva, cuja causa ativa é a circulação das mercadorias \{"o movimento do dinheiro (...) [é - cmg] apenas a expressão da circulação de mercadorias" (OCI/1, p. 226)\}. São os capitalistas industriais e comerciais, como parte ativa, que realizam estas operações monetárias, cabendo ao capital de comércio de dinheiro apenas a função passiva de realizar as operações técnicas que aquelas exigem, como, por exemplo, executar e registrar pagamentos e cobranças, atualizar as contas correntes, realizar compensações de pagamentos, e assegurar a guarda das reservas líquidas dos capitalistas, base do comércio de crédito. O capital comercial, em contraste enfatizado e repetido por Marx, assume as funções ativas dos capitalistas industriais na circulação. 
formas diferentes: os capitais comercial e bancário obtêm a sua parte na forma de cobertura dos seus custos de circulação e lucros; os proprietários de terras e o Estado, na forma de renda da terra e de tributos, respectivamente. Com exceção do capital comercial, os demais beneficiários, incluindo o capital bancário, obtêm as suas respectivas frações da mais-valia total após a formação da taxa média de lucro. A fração correspondente ao capital comercial, ao contrário, é transferida a este no próprio processo, do qual participa, de formação da taxa média de lucro geral, como se verá a seguir.

\subsection{O Capital de Comércio de Mercadorias ou Capital Comercial}

A primeira fração, analisada por Marx, que se desprende da mais-valia é a transferida ao capital comercial. A incorporação do capital comercial à análise de Marx é crucial para o estabelecimento da forma, considerada por ele definitiva, da taxa média de lucro - por este motivo intitulada, aqui, taxa média de lucro geral $\left(\overline{l_{g}^{\prime}}\right)$ - e dos preços de produção e para a realização do lucro comercial (OCIII/1, p. 213-226). Este é o aspecto do capital comercial ao qual se deseja dar destaque. Tal como ocorre no caso da rotação, os textos que tratam da teoria da taxa média de lucro de Marx geralmente não fazem referência à influência do capital comercial, detendo-se na análise exposta na seção II do OCIII, como já mencionado. Nesta, o capital mercantil é ignorado por Marx, pela razão puramente analítica, também já mencionada, de que a gênese industrial do lucro médio deve ser examinada e exposta antes da análise da sua distribuição ${ }^{21}$. Na realidade, como Marx procura demonstrar detalhadamente, a transferência de parte da mais-valia ao capital comercial não é posterior à formação da taxa média de lucro, uma vez que aquele participa da própria formação desta.

Com a inclusão do capital comercial, a taxa média de lucro não é mais determinada pela relação entre a mais-valia total e o capital industrial total, mas entre a mais-valia total, conforme (5), e a soma dos capitais industriais e comerciais (OCIII/1, p. 216), como em (6) abaixo, nas formas sintética e expandida, respectivamente:

\footnotetext{
${ }^{21}$ Ao esclarecer o raciocínio que empregara na exposição da seção II (formação da $\overline{l_{i}^{\prime}}$ ), Marx lembra que "[estava então pressuposto] que o capital mercantil (aqui só trataremos do mesmo enquanto capital de comércio de mercadorias) não entra na formação da taxa geral ou média de lucro. Partimos ... desse pressuposto ... porque, naquele momento, o capital mercantil enquanto tal ainda não existia para nós e, [...] porque o lucro médio, e portanto a taxa geral de lucro, de início tinha de ser desenvolvido necessariamente como equalização dos lucros ou mais-valia, realmente produzidos pelos capitais industriais das diferentes esferas da produção. [...] Agora é necessário, pois, complementar a exposição anterior" (OCIII/1, p. 215, acréscimos próprios). Marx retoma este esclarecimento no início da análise do capital portador de juros: "Ao considerar pela primeira vez a taxa geral ou média de lucro (seção II deste livro) ainda não tínhamos esta última diante de nós em sua figura definitiva, pois a equalização aparecia apenas como equalização dos capitais industriais investidos nas diferentes esferas. Isso foi completado na seção anterior, em que a participação do capital comercial nessa equalização e o lucro comercial foram discutidos. [...] No prosseguimento da exposição não se deve perder de vista que, daqui por diante, ao falar da taxa geral de lucro ou do lucro médio, nos referimos à última versão, isto é, à figura definitiva da taxa média" (Ibidem, p. 255, itálicos acrescentados).
} 


$$
\bar{l}^{\prime}=\frac{m}{C_{i n}+C_{c o}} \quad \text { ou } \quad \overline{l_{g}^{\prime}}=\frac{\bar{n}_{p} m^{\prime} \sum v_{i}}{\sum \mathrm{C}_{i}^{i n}+\sum \mathrm{C}_{j}^{c o}}
$$

em que $C_{i n}$ e $C_{c o}$ (C maiúsculos) são os capitais industrial e comercial ${ }^{22}$ totais agregados da economia, e $i$ e $j$ referem-se aos setores em que se dividem, respectivamente.

Não se pode reproduzir neste artigo, por não ser seu objetivo, a demonstração da formação do lucro comercial por Marx, exposta no capítulo 17 de OCIII. Contribui, no entanto, para o entendimento do tema aqui tratado, mencionar que a transferência de valor do capital industrial ao capital comercial dá-se porque o comerciante compra a mercadoria do produtor a um preço menor que o preço de produção, e a revende ao preço de produção, acrescentando a diferença em relação ao preço de aquisição, e nesta diferença reside o seu lucro e a cobertura dos seus custos de circulação ${ }^{23}$. A compra abaixo do preço de produção dá-se porque a taxa média de lucro, ao ser reduzida devido à participação do capital comercial na sua formação, segundo a fórmula (6), e ao incidir sobre o preço de venda do capitalista industrial $\left(p_{v}=k+\bar{l}^{\prime} C_{i n}\right)$, o reduz na proporção da diferença entre as fórmulas (6) e (5), nas quais $\sum C_{i}^{i n}$ e $\sum C_{i}$, respectivamente, representam o capital industrial, apenas em notações diferentes ${ }^{24}$.

Com base em (6), obtém-se uma formalização da determinação teórica da taxa média de lucro geral que inclui todos os elementos fundamentais indicados por Marx. De $q_{o}=c / v$ obtém-se $c=q_{o} \cdot v$, ou $\sum c_{i}=q_{o} \sum v_{i}$. Substituindo este elemento em $\sum C_{i}^{i n}=$ $\sum c_{i}+\sum v_{i}$ e recorrendo a uma manipulação matemática simples, que consiste em dividir o numerador e o denominador por $\sum v_{i}$, introduz-se o efeito da composição orgânica na fórmula, e se obtém

\footnotetext{
22 Observe-se que o capital comercial se compõe do capital de aquisição, necessário à compra das mercadorias pelo comerciante, e do capital adicional necessário à cobertura dos custos puros de circulação. "Quer circulante, quer fixo, todo esse capital adicional entra na formação da taxa geral de lucro [trata-se agora da taxa média de lucro geral $\overline{l_{g}^{\prime}}$, como aqui proposto]" (OCIII/1, p. 218, acréscimos próprios). Esclarecimentos detalhados sobre este processo podem ser obtidos em (GERMER; BELOTO, 2006).

${ }^{23}$ Esta descoberta de Marx explica a impressão do senso comum, de que o lucro é simples lucro de alienação, isto é, resultante de mero acréscimo do lucro pretendido ao preço de custo das mercadorias (ver Nota de rodapé $31)$.

24 "Na formação da taxa geral de lucro [taxa média de lucro geral - $\overline{l_{g}^{\prime}}$ ], o capital comercial entra de modo determinante pro rata da parte que ele constitui do capital global. [...]. Mas esse lucro médio [na realidade tratase da taxa média de lucro] é agora determinado de outro modo. É determinado pelo lucro [mais-valia] global que o capital produtivo total gera; mas não é calculado sobre esse capital produtivo total [...], mas calculado sobre o capital produtivo total + capital comercial, de tal modo que, se há 900 de capital produtivo e 100 de capital comercial, a taxa média de lucro é $180 / 1000=18 \%$. O preço de produção é, portanto $=\mathrm{c}($ custos $)+18$, em vez de $=\mathrm{c}+20$. Na taxa de lucro já está calculada a parte do lucro global que cabe ao capital comercial" (OCIII/1, p. 216, acréscimos próprios).
} 


$$
\overline{l_{g}^{\prime}}=\frac{\frac{\bar{n}_{p} m^{\prime} \sum v_{i}}{\sum v_{i}}}{\frac{\left(q_{o}+1\right) \sum v_{i}}{\sum v_{i}}+\frac{\sum \mathrm{C}_{j}^{c o}}{\sum v_{i}}} \quad \text { que resulta em } \quad \overline{l_{g}^{\prime}}=\frac{\bar{n}_{p} m^{\prime}}{\left(q_{o}+1\right)+\frac{\sum \mathrm{C}_{j}^{c o}}{\sum v_{i}}}
$$

fórmula na qual a taxa média de lucro geral aparece como função de todos os fatores relevantes apontados por Marx: a taxa de mais-valia, a composição orgânica do capital, a rotação do capital variável industrial, e o capital comercial, com exceção apenas da distribuição setorial do capital industrial.

A formalização permite visualizar mais claramente as influências dos diversos fatores na formação da taxa média de lucro geral. Pode-se ver que, à primeira vista, a inclusão do capital de comércio de mercadorias tem como efeito a redução da taxa média de lucro, em relação à taxa encontrada quando a mais-valia produzida é relacionada apenas ao capital industrial. Isto, em princípio, aplicado à análise de um período mais longo, teria como efeito deslocar a curva de tendência para baixo ou para cima, caso a proporção do capital comercial no capital total permaneça constante no período coberto pela curva. Alterando-se, porém, esta proporção, a taxa média de lucro geral se alterará para mais ou para menos, caso a proporção do capital comercial se altere, respectivamente, para menos ou para mais. Por outro lado, as proporções dos capitais de comércio de mercadorias e de dinheiro podem mover-se no mesmo sentido ou em sentidos contrários e, nos dois casos, segundo taxas de variação iguais ou diferentes. Deve-se notar também que estas variações podem ter uma relação definida com as fases do ciclo econômico, aspecto merecedor de pesquisa específica, de modo que os efeitos destas variações sobre a taxa média de lucro podem ser bastante variados.

O termo $\frac{\sum c_{j}^{c o}}{\sum v_{i}}$, do denominador, implica que, quanto maior ele seja, menor será a $\overline{l_{g}^{\prime}}$, e o termo será tanto maior quanto maior for o capital comercial em relação ao capital variável (lembrando que este representa a força de trabalho do setor industrial), e se pode, fundamentadamente, sugerir que este termo possui tendência de aumentar: por um lado, na medida que a composição orgânica do capital aumenta, a proporção do capital variável, no capital industrial, será menor; por outro lado, como a massa do capital industrial estará aumentando com a acumulação, pode-se supor que o mesmo tenderá a ocorrer com o capital comercial, do que resultaria uma tendência de aumento do termo indicado e, como consequência, este termo reforça a tendência de queda da taxa média de lucro.

Já o termo $\bar{n}_{p} m^{\prime}$ reforça a barreira à queda da taxa média de lucro, representada pela taxa de mais-valia, caso seja consistente esperar que a rotação do capital tenha tendência a aumentar. A introdução da rotação dá destaque ao fato de que a mais-valia total não depende apenas de m'e v, mas também da rotação do capital industrial.

Isto indica que a omissão da forma definitiva ou geral da taxa média de lucro pode ter consequências importantes na interpretação dos eventos econômicos, ao ignorar os efeitos sobre a taxa média de lucro de variações na magnitude e na operação do capital mercantil nas suas duas formas. 
É a forma sintética da fórmula (6) da taxa média de lucro que Marx considerou ser a definitiva ${ }^{25}$, e causa surpresa o fato de não ser reconhecida em discussões sobre a taxa média de lucro na teoria de Marx, que se referem à fórmula (1), fazendo pouca, ou nenhuma, referência à forma sintética definitiva (6), e menos ainda à forma expandida da mesma. Com efeito, compreende-se que esta última torna difícil a derivação de fórmulas elegantes, a partir da fórmula (1), como a feita por Sweezy (1976), já citada, e que, se podia ser corrigida em relação à rotação do capital industrial, não admite o mesmo no que se refere ao capital comercial.

Isto, no entanto, não resolve todo o problema, porque, como já lembrado, o capital mercantil "se divide em duas formas ou subespécies": o capital comercial $\left(C_{c o}\right)$ e o capital bancário $\left(\mathrm{C}_{\mathrm{b}}\right)(\mathrm{OCIII} / 1$, p. 203), e porque, neste último, o comércio de dinheiro combinase com o comércio de crédito, isto é, comércio de capital portador de juros, cuja natureza é distinta do comércio de dinheiro. Esta circunstância exige que o capital mercantil seja analisado mais detalhadamente, a fim de que a natureza do capital bancário seja adequadamente esclarecida.

Para Marx a incorporação do capital comercial à análise era o ingrediente final para a formação da taxa média de lucro na forma definitiva. No entanto, o segmento de comércio de dinheiro do capital bancário, segundo o critério deste artigo, exposto adiante, em princípio deveria ser incorporado também, uma vez que possui propriedades análogas às do segmento de comércio de mercadorias o que está implícito no fato de que o próprio Marx os concebeu, com fundamento incontestável, como subdivisões da mesma forma do capital. Por este motivo, foi hipótese inicial da presente pesquisa, que o capital comercial, que realiza as funções do capital industrial na circulação, e que completa a formação da taxa média de lucro geral, deveria ser entendido não apenas como capital comercial, mas como capital mercantil, isto é, o conjunto das suas duas formas: o capital comercial mais a fração do capital bancário dedicada ao comércio de dinheiro. Marx, no entanto, não entendeu assim, pelas razões que se exporá.

\subsection{O Capital Bancário}

O capital bancário ocupa um lugar precisamente determinado na rede interligada de capitais, que constitui a economia capitalista. Como, segundo a concepção de Marx, o capital bancário engloba as funções de comércio de dinheiro e comércio de crédito, ele seria representado, atualmente, pelos bancos comerciais, que desempenham as duas funções mencionadas ${ }^{26}$. No entanto, como as duas funções - de comércio de dinheiro e de

\footnotetext{
${ }^{25}$ A forma expandida inclui a rotação, que Marx ainda não havia incorporado, como anunciara que faria.

${ }^{26}$ Embora fundidas nos bancos comerciais, as duas funções podem separar-se, e na prática se separam, cada uma dando origem a diferentes tipos de instituições bancárias. A estrutura do sistema bancário é complexa, englobando diversos tipos de instituições, mas, como todas desempenham uma ou outra, ou as duas atividades mencionadas combinadas, os bancos comerciais podem ser considerados representativos de ambas, de modo que o enfoque proposto se justifica.
} 
crédito, respectivamente - são essencialmente distintas ${ }^{27}$, o título de 'capital de comércio de dinheiro', mantido por Marx para designar a categoria teórica que engloba ambos os capitais, causa certa confusão ao leitor e ao debate do tema. Adicionalmente, a utilização do mesmo título para o capital que realiza as duas funções, faz supor que o comércio de dinheiro seja a mais relevante do capital bancário. No entanto, apesar da precedência, na gênese do capitalismo ${ }^{28}$, do comércio de dinheiro propriamente dito, Marx considera que a incorporação do comércio de crédito às suas atividades é o que sinaliza o pleno desenvolvimento deste capital, e destaca o fato de que "a parte incomensuravelmente maior do lucro do comerciante de dinheiro é constituída pelo juro sobre o capital que empresta" (MARX, 1980, II/3.5, p. 1701).

Como o próprio Marx e, após ele, Hilferding (1985), se referiram à atividade creditícia como comércio de crédito, e como cada uma destas atividades requer uma determinada massa de capital, e como, adicionalmente, a rentabilidade derivada das duas atividades possui determinantes distintos, como se procurará esclarecer, convém introduzir explicitamente uma diferenciação entre as duas atividades e os respectivos capitais nelas envolvidos $^{29}$. Como, por outro lado, o capital investido em um banco comercial necessariamente engloba as duas atividades, justifica-se a utilização, neste artigo, do título de capital bancário para designar especificamente este capital conjunto.

Sendo assim, o capital bancário, representado, nos dias de hoje, tipicamente pelo banco comercial, decompõe-se em duas partes, cada uma delas dedicada à realização da sua função específica, de modo que este capital seria representado pela seguinte fórmula:

$$
C_{b}=C_{c d}+C_{c r}
$$

Em que $C_{c d}$ representa o capital de comércio de dinheiro e $C_{c r}$ o capital de comércio de crédito.

\footnotetext{
${ }^{27}$ Marx refere-se ao "comércio de dinheiro, na sua forma pura, ..., isto é, separado do sistema de crédito..." (OCIII/1, p. 241).

${ }^{28} \mathrm{Na}$ perspectiva histórica mais longa, a precedência pertence, segundo Marx, ao comércio de crédito: "o capital portador de juros, ou (...) em sua forma antiga, o capital usurário, pertence, com seu irmão gêmeo, o capital comercial, às formas antediluvianas do capital, que por longo tempo precedem o modo de produção capitalista" (OCIII/2, p. 107).

${ }^{29} \mathrm{O}$ fato de as duas massas de capital se confundirem na atividade bancária e serem de separação prática difícil, não significa que isto não possa ou deva ser feito, tanto prática quanto teoricamente. $\mathrm{O}$ mesmo ocorre em outros casos, como, por exemplo, na combinação de atividades industriais no capital de comércio de mercadorias, ou na subdivisão meramente analítica de uma mesma indústria em duas partes, uma inserida no departamento de meios de produção e outra no de meios de consumo, como é o caso das indústrias automobilística, de materiais de construção, e outras.
} 


\subsubsection{Segmento de Comércio de Dinheiro}

Antes de ingressar diretamente na análise do tema, é oportuno situá-lo, assim como o tema mais amplo no qual se insere - o do capital mercantil - no processo de elaboração d'OCIII. É preciso iniciar mencionando a importante distinção, feita por Marx, entre os modos de 'pesquisa' e de 'exposição' (OCI/1, p. 20), cuja relevância, nem sempre percebida, foi apontada, porém, por diversos autores (ex. ILIENKOV, 1982, cap. 3; GERMER, 1997, p. 114; NETTO, p. 27), e se revela nitidamente n'OCIII. Isto significa que há temas, ou aspectos de temas, em cujo tratamento Marx encontra dificuldades, refletidas na progressão hesitante do pensamento, na intercalação de lembretes para aprofundar, etc., que indicam que Marx se encontra em pleno 'modo de pesquisa', debatendo-se ainda com as perguntas que a mesma deve responder, em nítido contraste com outros temas ou aspectos, expostos com segurança e sem nenhuma hesitação, que focalizam os resultados já obtidos na pesquisa, e que são exemplos do 'modo de exposição' ${ }^{30}$.

A seção IV d'OCIII, agora analisada, ilustra ambos os métodos mencionados por Marx. Combinam-se aspectos do tema em que Marx ainda está tateando, sem ter chegado, portanto, a uma conclusão definitiva. O capítulo 17, sobre o lucro comercial, é um exemplo típico do 'modo de pesquisa', onde o mesmo problema - o papel do capital variável comercial - é reposto diversas vezes, sem ter sido, aparentemente, solucionado. Em contraste com isso, o capítulo 19, sobre o capital de comércio de dinheiro, é nitidamente uma apresentação enxuta e segura de resultados já alcançados, e isso desde a primeira redação disponível (MARX, 1980, II/3.5, p. 1701), sendo, portanto, um exemplo do 'modo de exposição'. O próprio Marx comenta, já neste início da pesquisa do tema, que "o lucro do comércio de dinheiro não oferece a mesma dificuldade que o do capital comercial" (Ibidem, loc. cit.) ${ }^{31}$.

As abordagens de ambos os capítulos, nos originais d'OCIII (MARX, 1992), não apresentam novidades teóricas em relação aos manuscritos de 1861-63. Como o entendimento de Marx sobre o capital de comércio de dinheiro parece seguro, o que se deve sublinhar é o fato de aparentemente não ter conseguido avançar, neste intervalo, na

\footnotetext{
${ }^{30}$ É "necessário distinguir o modo de exposição formalmente do modo de pesquisa. A pesquisa tem de captar detalhadamente a matéria, analisar as suas várias formas de evolução e rastrear sua conexão íntima. Só depois de concluído esse trabalho é que se pode expor adequadamente o movimento real" (OCI/1, p. 20, tradução livre), ou seja, a pesquisa é a busca incerta da explicação, a exposição é a apresentação organizada, autoconfiante, da explicação encontrada.

${ }^{31}$ A dificuldade da explicação, no caso do lucro do capital comercial, explica o retorno contínuo ao problema do capital variável comercial, mencionado acima: neste caso "a dificuldade decorre do fato de que o lucro resulta da majoração dos preços das mercadorias e estas são vendidas mais caro que compradas, o que parece contradizer a determinação dos preços de produção e, por fim, dos valores das mercadorias, pelo tempo de trabalho" (MARX, 1980, p. 1701). O problema, para Marx, residia na aparência de que o capital comercial pratica 'lucro de alienação', isto é, a concepção de que o lucro decorre simplesmente de um acréscimo arbitrário ao custo do produto, tido ainda, na época de Marx, por autores reconhecidos, como causa do lucro, que Marx criticou na crítica a Steuart (MARX, 1977, p. 333-7; OCIII/1, p. 293), e cuja falácia demonstrou n'OCI/1 (p. 136-8).
} 
explicação do lucro comercial - impedido pelo problema do papel do capital variável comercial -, que permanece com a mesma redação hesitante. Mas isto refere-se à interpretação teórica do capital variável comercial, enquanto a participação do capital comercial na formação da $\bar{l}_{g}^{\prime}$ parece definida, como definida está a exclusão do capital de comércio de dinheiro da mesma, mas sem que os motivos exatos tenham sido determinados. Estes motivos são o tema da presente seção.

Há um aspecto do tema mais amplo - a seção do capital mercantil em conjunto em que se revela não a natureza de problemas específicos, mas a insuficiência frequentemente mencionada na literatura, às vezes maliciosamente ${ }^{32}$ - de finalização ou revisão da obra para publicação. Isto, no entanto, na maior parte dos casos, afeta apenas o aspecto editorial do tema, não o conteúdo, e apenas partes determinadas da obra, não a sua totalidade. O problema é que a exposição não dá destaque ao fato de que as seções IV (que focaliza o capital mercantil como um todo, mas com mais destaque para o capital comercial) e V (O capital portador de juros) estão conectadas. A conexão entre as duas seções consiste no fato, já exposto, de que o capital de comércio de dinheiro (aqui denominado capital bancário) desempenha duas funções, uma das quais, a menos relevante teoricamente, é analisada muito brevemente no capítulo 19 (seção IV), enquanto a outra, a função principal, do comércio de crédito, é desenvolvida extensamente na seção $\mathrm{V}^{33}$.

A primeira função é a de comércio de dinheiro "na sua forma pura, ..., isto é, separado do sistema de crédito" (OCIII/1, p. 241); e a segunda é o comércio de crédito, denominado capital portador de juros ${ }^{34}$, que se desdobra em diversas e importantes consequências. Embora esta conexão seja indicada em duas ou três ocasiões, isto não é feito com destaque, nem as suas implicações são apontadas, de modo que fica obscurecida e geralmente não é percebida pelos leitores da obra. Para isto contribui também a escassez de referências, e talvez mesmo de simples leituras da seção IV, pelos estudiosos d'O capital, exceto no que diz respeito ao capítulo 20, de caráter histórico. A isto acrescenta-se o fato de que esta conexão não é mencionada no parágrafo inicial do capítulo 21 , dedicado a uma breve revisão da seção IV, sem, no entanto, mencionar o capital de comércio de dinheiro,

\footnotetext{
32 É o caso de alguns colaboradores do projeto Mega 2, que parecem mais empenhados em desconstruir $O$ capital e lançar suspeição sobre os esforços de Engels na organização da edição do livro III da obra, do que no aprofundamento da sua compreensão.

33 "Completamente desenvolvido está o comércio de dinheiro, (...) assim que a suas funções restantes se combina a de conceder e receber empréstimos e a do comércio de crédito. Sobre isso, na seção seguinte, ao tratar do capital portador de juros" (OCIII/2, p. 240).

${ }^{34} \mathrm{O}$ caráter de 'comércio' do capital portador de juros, expresso na função de comércio de crédito, é coerente com a concepção de Marx, do capital portador de juros como mercadoria-capital, isto é, o fato de que, nesta condição, o capital ingressa na circulação não nas duas formas assumidas pelo capital industrial na circulação - capital mercadoria ou capital monetário -, mas na forma direta de mercadoria - a mercadoria-capital -, cujo valor de uso é a capacidade de gerar mais-valia, uma vez aplicado como capital industrial.
} 
título que, ademais, não é mais lembrado em toda a seção $\mathrm{V}^{35}$. A terminologia das categorias teóricas, na seção $\mathrm{V}$, também se altera em relação à seção IV. Assim, o comerciante não se denomina comerciante de dinheiro ou de crédito, mas prestamista ou banqueiro.

A constatação destas limitações na exposição desta parte da obra, desigualmente distribuídas nas duas sessões, e das categorias não suficientemente claras ou cujos aspectos essenciais não são adequadamente destacados, além da progressão truncada da apresentação, que nem sempre chega a uma conclusão clara, como no caso da explicação do papel do capital variável comercial, já mencionado, são circunstâncias que perturbam a leitura e dificultam ou retardam o entendimento imediato da opinião do autor. Esta situação é a que se constatou no estudo do problema do papel do capital de comércio de dinheiro, principalmente da sua fundamentação, na formação da $\overline{l_{g}^{\prime}}$, e em diversos aspectos relevantes do problema.

\subsubsection{Formalização do Movimento do Capital de Comércio de Dinheiro Isoladamente}

As atividades do $C_{c d}$ consistem apenas na realização das operações técnicas, já expostas, inerentes à circulação monetária e decorrentes da circulação das mercadorias (OCIII/1, p. 241). Cada uma destas operações implica um custo, que, acrescido do lucro do prestador dos serviços, constitui a tarifa ${ }^{36}$. Observe-se que, diferentemente do capital de comércio de mercadorias, cuja apropriação da sua parte da mais-valia ocorre de modo encoberto, por dentro do processo de formação da taxa média de lucro, no capital de comércio de dinheiro ela se dá às claras, via pagamento de um preço, a tarifa.

Tal como o capital de comércio de mercadorias, o de comércio de dinheiro, embora executor de uma das funções do capital industrial, também não possui o estágio produtivo $\mathrm{P}$, portanto também não produz mais-valia, de modo que, tanto o custo em que incorre quanto o lucro que obtém, são provenientes de transferências da mais-valia gerada pelo capital industrial, pois o trabalho comercial, não sendo produtivo, também não conserva nem transfere o valor dos elementos do capital constante comercial ao valor das mercadorias em circulação. Marx apresentou um esboço de formalização do movimento do capital comercial, resumido acima, mas não o fez, de modo explícito, para o capital de comércio de dinheiro, mas a sua exposição autoriza fazer hipóteses sobre qual poderia ser a sua opinião, uma das quais é apresentada na seção seguinte.

\footnotetext{
${ }^{35}$ Não por acaso, esta foi a 'dificílima seção V', que opôs as maiores dificuldades ao trabalho de edição d'OCIII por Engels, por ser a que se encontrava em menor estado de elaboração e/ou redação final por Marx, segundo o prefácio de Engels (OCIII/1, p. 6-9), por este motivo também preferida pelos críticos hostis.

36 “[...] esse movimento constante de parte do capital existente como dinheiro, separado da própria funçãocapital, essa operação puramente técnica é o que ocasiona trabalho e custos especiais - custos de circulação" (Ibidem, p. 238).
} 
Alguns conceitos elementares referentes ao movimento do capital de comércio de dinheiro podem ser explicitados. Em primeiro lugar, as tarifas bancárias representam, tal como os custos de comercialização, um custo de circulação do capital industrial, que incide sobre os estágios de circulação deste, uma vez que as funções monetárias, realizadas pelos bancos, são indispensáveis à circulação das mercadorias e teriam que ser realizadas pelos próprios capitalistas industriais e comerciais, caso os bancos não existissem. À primeira vista as tarifas bancárias, pagas por capitalistas industriais e comerciais aos bancos, devem ser concebidas como deduções do lucro médio, e neste caso seriam formalmente idênticas aos juros, que igualmente o são. No entanto, o pagamento de juros tem consequências operacionais e ideológicas importantes, que se refletem, teoricamente e na prática, na divisão do lucro médio em lucro do empresário e juro.

A concepção da teoria vulgar, destes dois componentes do lucro médio como dois rendimentos qualitativamente diferentes - como indicado por Marx -, emanando de duas diferentes funções do capital, é um produto ideológico da cristalização mental diferenciada dos dois fluxos na atividade prática do capital. Com o lucro do empresário e o juro atribuídos a funções distintas do mesmo capital - a função produtiva e a função propriedade, respectivamente -, o juro constitui, na economia vulgar, um fluxo que parece existir independentemente da tomada de crédito, e que flui para o próprio capitalista produtivo ou comercial, ao invés de para o banco, caso o capitalista não recorra ao crédito, sendo assim registrado formalmente na contabilidade ${ }^{37}$. Havendo crédito, é o banco o proprietário do capital, portanto é para ele que flui o juro gerado de qualquer modo pelo mesmo. Se o mesmo raciocínio pudesse ser aplicado às tarifas pagas pelas operações de comércio de dinheiro, o lucro médio seria dividido em três partes, ao invés de duas, acrescentando-se as tarifas bancárias ao lucro do empresário e juros. Nada semelhante, porém, é sugerido por Marx no que se refere ao comércio de dinheiro, nem parece plausível.

Por outro lado, deve-se a Hilferding uma contribuição significativa à demonstração das diferenças essenciais entre os capitais de comércio de dinheiro e de crédito, tanto no que diz respeito à determinação teórica do capital investido, quanto do lucro obtido nestas duas atividades, e da semelhança entre os capitais de comércio de mercadorias e de dinheiro, respectivamente. Hilferding explicitamente concebe os capitais de comércio de mercadorias e de dinheiro como idênticos, do ponto de vista das formas de dimensionamento do capital e da obtenção do lucro, ao mesmo tempo que diferencia nitidamente os segmentos de comércio de dinheiro e de crédito do capital bancário (HILFERDING, 1985, p. 169-174).

O dimensionamento dos capitais de comércio de mercadorias e de dinheiro "é dado tecnicamente, determinado pelas condições objetivas do processo de produção e de circulação" (Ibidem, p. 170 e 172). Isto é, até certo ponto, intuitivo, uma vez que ambos os capitais são apenas formas autonomizadas dos segmentos correspondentes da fase M'-D' do capital industrial, e realizam funções que, na sua ausência, como já lembrado, os

37 Deve-se aduzir que isto uniformiza o cálculo capitalista, pois, caso contrário, as taxas de lucro se diferenciariam segundo as diferentes proporções de capitais próprio e de empréstimo dos diferentes capitais. 
próprios capitalistas industriais teriam que realizar, funções que dependem das dimensões e da estrutura técnica dos capitais industriais e do processo de reprodução. Como consequência, os capitais industrial, comercial e de comércio de dinheiro "são partes determinadas do capital social que, num momento dado, devem existir numa determinada relação entre si" (Ibidem, p. 174). Sendo assim, a dimensão do capital de comércio de dinheiro seria determinada pela relação proporcional seguinte:

$$
C_{c d}=\delta C
$$

em que $C_{c d}$ e $C$ representam o capital investido no comércio de dinheiro e o capital social total, respectivamente, sendo $\delta$ a proporção do capital de comércio de dinheiro no capital total $C$, sendo $C=C_{i}+C_{c m}+C_{c d}$.

Como forma do capital mercantil, o lucro do capital de comércio de dinheiro consiste no lucro médio e forma-se, portanto, tal como nos casos dos capitais industrial e comercial, pela imposição da taxa média de lucro geral sobre o capital investido ${ }^{38}$ :

$$
\bar{l}_{c d}=\overline{l_{g}^{\prime}} \cdot C_{c d}
$$

em que $\bar{l}_{c d}$ e $C_{c d}$ representam o lucro médio e o capital investido no comércio de dinheiro, respectivamente.

Neste caso $C_{c d}$ representa D da fórmula D-M-D'. Ou seja, D' consiste na soma do custo de realização dos serviços bancários (representada por M) acrescido do lucro médio, e este resulta da imposição da taxa média de lucro geral, $\overline{l_{g}^{\prime}}$, ao capital investido pelo banco. O capital investido, por sua vez, é dimensionado segundo a magnitude dos serviços bancários correspondentes ao comércio de dinheiro, que são determinados pelas características da circulação dos capitais industrial e comercial.

Para o capitalista industrial ou comercial que utiliza os serviços do banco, as tarifas só podem ser interpretadas, portanto, como uma dedução do lucro médio (OCIII/1, p. 242), uma vez que os custos da força de trabalho e dos meios de circulação bancários não são componentes do capital produtivo, portanto não integram $c$ nem $v$. Isto significa que o que se adquire com as tarifas não são componentes dos meios de produção do capital industrial. O problema consiste em como, neste caso, D se converte em D'. Marx não deixou indicação a esse respeito, ao contrário do que fez no caso do capital de comércio de mercadorias, e por um possível motivo que será sugerido na seção seguinte.

\footnotetext{
38 "Os bancos realizam o lucro médio sobre esse capital, do mesmo modo que os comerciantes o fazem sobre o capital de comércio de mercadorias e os industriais sobre o capital de produção" (HILFERDING, 1985, p. 170).
} 


\subsubsection{O Papel do Capital de Comércio de Dinheiro na Formação da $\overline{l_{g}^{\prime}}$}

A concepção dos capitais de comércio de mercadorias e de dinheiro, respectivamente, como espécies de uma mesma categoria, induz, à primeira leitura, à impressão de que o capital de comércio de dinheiro deveria funcionar, em relação à formação da $\overline{l_{g}^{\prime}}$, de modo idêntico ao capital de comércio de mercadorias, isto é, participando também da sua formação. Mas o leitor surpreende-se ao constatar a clara rejeição desta opção por Marx, descartando decididamente a participação do capital de comércio de dinheiro na formação da $\overline{l_{g}^{\prime}}$. A partir desta constatação foi necessário reiniciar o estudo dos textos, desde os Grundrisse e passando pelos Manuscritos econômicos de 1861-63 e pelos manuscritos originais d'OCIII, a fim de identificar os argumentos exatos que fundamentam esta opinião. O resultado desta pesquisa é que os pontos decisivos da sua fundamentação teórica, resumida a seguir, não transparecem com a necessária clareza, devido às circunstâncias já expostas, além de que Marx apresenta diferentes justificativas, nenhuma das quais se destaca como decisiva para a exclusão do capital de comércio de dinheiro da formação da $\overline{l_{g}^{\prime}}$, razão pela qual também não é fácil resumi-la, de modo que se procurará expô-la e discutir, tanto quanto possível, os argumentos de Marx.

$\mathrm{O}$ argumento que parece mais importante, e que é repetido por Marx diversas vezes no cap. 19, diz respeito ao modo de atuar do capital de comércio de dinheiro, que se diferencia qualitativamente do modo do capital de comércio de mercadorias. Este último assume integralmente uma das funções do capital industrial no terceiro estágio do seu ciclo, que é a colocação em circulação da mercadoria, M'-D'. O comerciante adquire a mercadoria do capitalista industrial e passa a ser responsável pela busca de compradores e pela efetiva venda, na qual a mercadoria realiza o seu valor ou preço de produção. Ou seja, é o comerciante, não o capitalista industrial, que faz circular a mercadoria e realiza o seu preço de produção, portanto assume materialmente a realização do último estágio do ciclo do capital industrial.

O fato de que o mesmo não ocorre com o capital de comércio de dinheiro é o fundamento da relevância do argumento citado acima: o capital de comércio de dinheiro não assume funções diretas do ciclo do capital ${ }^{39}$. Para destacar a especificidade do capital de comércio de dinheiro neste aspecto, Marx ressalta que este não só não assume, materialmente, funções do capitalista industrial, como nem sequer interfere nas características da própria circulação monetária, que por sua vez é mera expressão da

\footnotetext{
39 Efetivamente, Marx afirmou que o comércio de dinheiro distingue-se 'essencialmente' do comércio de mercadorias, devido ao fato de que este último "medeia a metamorfose da mercadoria e o intercâmbio de mercadorias ou ... inclusive faz esse processo do capital-mercadoria aparecer como processo de um capital distinto do capital industrial', enquanto o comércio de dinheiro 'só tem a ver ... com a técnica de um momento da circulação de mercadorias, a saber da circulação monetária, e com as diversas funções do dinheiro daí decorrentes", razão pela qual "não é possível demonstrar uma forma igualmente específica para o capital de comércio de dinheiro" (OCIII/1, p. 241).
} 
circulação das mercadorias, o que significa que, para o capital de comércio de dinheiro, as características da circulação monetária estão dadas. Para dar destaque ao papel subalterno do comércio de dinheiro, Marx afirma repetidas vezes que este realiza apenas as operações meramente técnicas correspondentes aos diversos momentos da circulação monetária.

Ora, se o capital de comércio de dinheiro não realiza as operações monetárias, apenas fornece os meios técnicos para a sua realização, parece que não se pode dizer que $o$ capital monetário (como forma do capital industrial no terceiro estágio do seu ciclo) se converta em capital de comércio de dinheiro, ou o faz apenas parcialmente, ao contrário do que claramente ocorre com o capital-mercadoria, que se converte e autonomiza efetivamente na figura do capital comercial ${ }^{40}$. Isto só é válido, no entanto, enquanto nos atemos estritamente ao capital de comércio de dinheiro 'na sua forma pura' de comércio de dinheiro. Mas, se estendemos o conceito ao comércio de crédito, isto é, comércio do capital portador de juros ou da mercadoria-capital, o processo de autonomização é claro, pois o capital de comércio de dinheiro opera, no comércio de crédito, com as reservas líquidas ${ }^{41}$ dos capitalistas industriais e comerciais, que, na ausência do capital de comércio de dinheiro, teriam que ser operadas pelos próprios capitalistas industriais e comerciais.

Pode-se dizer, portanto, que as reservas líquidas dos capitalistas convergem e se concentram nos bancos comerciais ${ }^{42}$, como resultado das funções passivas de comércio de dinheiro, por estes realizadas. Estas operações, embora meramente técnicas, constituem necessidades objetivas da circulação dos capitais e da realização da mais-valia, e consequentemente base permanente da concentração das reservas líquidas de toda a classe

\footnotetext{
${ }^{40}$ Marx justifica este entendimento em longa passagem, da qual se apresenta apenas um extrato: "[...] toda a circulação monetária é, em seu volume, em suas formas e em seus movimentos, mero resultado da circulação de mercadorias, que, do ponto de vista capitalista, representa apenas o processo de circulação do capital [...], então é óbvio que o comércio de dinheiro não medeia apenas o mero resultado e o modo como se manifesta a circulação de mercadorias: a circulação monetária. Essa circulação de dinheiro, como um momento da circulação de mercadorias, está dada para ele. O que ele medeia são suas operações técnicas, que ele concentra, abrevia e simplifica. O comércio de dinheiro não forma os tesouros, mas fornece os meios técnicos para que esse entesouramento (...) seja reduzido a seu mínimo econômico [...]. O comércio de dinheiro facilita a compensação dos saldos, (...), mas não determina a conexão nem o volume dos pagamentos recíprocos. (...) $o$ volume e o número das compras e vendas são totalmente independentes do comércio de dinheiro. Este só pode abreviar as operações técnicas que as acompanham e, por esse meio, diminuir a massa de dinheiro em espécie necessária para sua rotação (OCIII/1, p. 241, itálicos acrescentados)".
}

${ }^{41}$ As reservas líquidas dos capitalistas industriais e comerciais são as frações monetárias dos seus capitais, que devem permanecer inativas por períodos maiores ou menores, segundo os casos e as circunstâncias, aguardando o momento de retornarem ao ciclo industrial.

42 Embora as reservas depositadas permaneçam em poder dos bancos, em grande parte, por períodos relativamente curtos antes de retornarem aos ciclos dos seus capitais, as retiradas contínuas são compensadas por depósitos também contínuos, de modo que se forma uma massa expressiva e relativamente estável de capitais ociosos, que se convertem em objeto de intensa atividade creditícia por parte do capital bancário na função ativa de comércio de crédito, que se apresenta como amplamente predominante. 
capitalista no sistema bancário, e o extraordinário poder que a função creditícia ${ }^{43}$ daí decorrente a ele confere ${ }^{44}$, constituem seus resultados necessários. Compreende-se, assim, que as duas funções são estreitamente interdependentes, sob a dominância da função creditícia, e cujos custos e ganhos conjuntos encontram sua síntese na taxa de juros e a consequente divisão do lucro médio em lucro do empresário e juro. Compreende-se também que, desta maneira, os custos de circulação impostos pelas 'operações meramente técnicas' dos bancos comerciais dissolvem-se na contabilidade dos juros, atividade principal, da qual aquelas são apenas pressupostos ${ }^{45}$, e o problema da expressão independente destes custos, em analogia com o que ocorre com os juros, exposto na seção anterior, desaparece, aparentemente convertido em falso problema.

Assim sendo, o capital de comércio de dinheiro não participa da formação da taxa média de lucro geral, mas participa, de modo objetiva e teoricamente determinado, do lucro médio, através do juro, dele deduzido formal e regularmente. Deste modo, "como fonte do ... lucro [do capital bancário] surge diretamente uma parte da própria mais-valia e o seu lucro apenas como participação nesta mais-valia" (MARX, 1980, p. 1701, acréscimos próprios).

Chega-se a esta conclusão, após considerável esforço, necessário para cobrir as lacunas da apresentação, já indicadas, e as descontinuidades próprias do objeto sendo pesquisado. Com isso percebe-se quão esclarecedor seria se a natureza do capital de comércio de dinheiro, como integração das funções de puro comércio de dinheiro, por um lado, e de comércio de crédito, por outro, fosse explicitado desde logo com destaque. O fato de não o ser deve-se, certamente, ao fato de Marx ainda não ter alcançado, nesta matéria, respostas a todas as perguntas, e não ter podido, por conseguinte, expor os resultados segundo o 'modo de exposição', caso em que, "espelhada idealmente [isto é, no pensamento] [...] a vida da matéria, talvez possa parecer que se esteja tratando de uma construção a priori" (OCI/1, p. 20, acréscimos próprios).

\subsubsection{Segmento de Comércio de Crédito}

O comércio de crédito, segundo o exposto, acrescenta-se ao comércio de dinheiro como consequência da função de guarda dos saldos líquidos dos capitalistas pelos bancos comerciais. O lucro decorrente do comércio de crédito possui uma natureza nitidamente

\footnotetext{
43 "Emprestar e tomar emprestado, assim como pagar e cobrar, tornam-se funções especiais do capital empregado no comércio de dinheiro" (MARX, 1980, p. 1700).

44 "... a parte desproporcionalmente maior dos lucros do comerciante de dinheiro é composto pelos juros sobre os capitais que empresta..." (Ibidem, p. 1701).

$45 \mathrm{Na}$ prática os rendimentos obtidos pelas duas formas de capital combinadas no capital bancário se entrecruzam. Como exemplo apenas ilustrativo pode-se citar o fato de que os bancos podem dispensar a cobrança de tarifas de serviços que presta, total ou parcialmente, sendo compensados pela manutenção de saldos médios ou mínimos em conta corrente, ou pela realização de determinadas aplicações, pelas empresas clientes, além de outras condições possíveis (JAFFEE, 1994, p. 539; MAYER et al, 1993 p. 146-7). Esta circunstância não afeta, porém, a legitimidade da distinção teórica.
} 
distinta do lucro que o banco obtém do comércio de dinheiro, o que não é afetado pelo fato de ambos se fundirem no lucro global do capital bancário. O esclarecimento desta distinção deve-se a Rudolf Hilferding, que explicita uma distinção implícita na exposição de Marx.

$\mathrm{Na}$ exposição que se segue focaliza-se separadamente os dois diferentes capitais que compõem o capital bancário e os seus diferentes modos de operar e de obter o lucro médio. Isto não invalida a concepção que se extraiu da exposição de Marx, do capital bancário como um bloco de duas funções diferentes, mas interdependentes, cujo lucro médio compõe-se das contribuições de duas frações de capitais distintas.

É necessário, portanto, expor a especificidade da formação do lucro do comércio de crédito. Esta exposição apoia-se na habilidosa formalização de Hilferding (1985, cap. 10). O lucro obtido do comércio de crédito consiste na diferença entre a massa de juros recebidos pelos bancos no crédito que concedem e a massa de juros pagos na captação, acrescidos estes dos custos de circulação (Ibidem, p. 170; ITOH, LAPAVITSAS, 1999, p. 95), e pode ser assim representado:

$$
\bar{l}_{c r}=j_{r}-\left(j_{p+} c c\right)
$$

em que $\bar{l}_{c r}$ representa o lucro médio do comércio de crédito, e $j_{r}$ e $j_{p}$ representam os juros recebidos e pagos, respectivamente, e $c c$ representa os custos de circulação.

Como se pode ver, o lucro do comércio de crédito pode ser estimado sem que se conheça a magnitude do capital investido nesta atividade ${ }^{46}$, bastando que se conheça as massas de juros pagos e recebidos, o que aponta para a especificidade do processo de formação do capital investido e do lucro nesta atividade. Com efeito, como mostrou Hilferding, enquanto no capital de comércio de dinheiro (tal como no de comércio de mercadorias) é o montante de capital investido na atividade que determina o lucro obtido, dada a taxa média de lucro, ou seja, $\bar{l}_{c d}=\overline{l_{g}^{\prime}} \cdot C_{c d}$, no capital de comércio de crédito dá-se o contrário, ou seja, é o lucro capaz de ser obtido na atividade que determina o máximo de capital que nela pode ser investido, dada a taxa média de lucro, a fim de que o capital investido possa obter o lucro médio.

O processo dá-se do seguinte modo: dada a massa de capital de empréstimo disponível, a taxa de juros recebida pelos bancos é determinada pela relação entre a oferta e a demanda de capital de empréstimo em termos globais e determina a massa de juros recebidos. A taxa de juros pagos pelos bancos é determinada pela concorrência entre eles na captação, e determina a massa de juros pagos (Ibidem, p. 171). A diferença entre ambos, deduzidos os custos de circulação, constitui a massa de lucro acessível ao capital aplicado no comércio de crédito. $\mathrm{O}$ capital que pode ser aplicado no comércio de crédito, por sua

46 "Por conseguinte, esse não é lucro no sentido categórico, e seu nível não é dado pela taxa média de lucro" (Hilferding, p. 170). 
vez, é determinado pela capitalização ${ }^{47}$, à taxa média de lucro, desta massa de lucro, pela fórmula seguinte:

$$
C_{c r}=\frac{l_{c r}}{\bar{l}^{\prime}}
$$

O processo pode ser ilustrado pelo exemplo clássico de Hilferding (Ibidem, p. 171): seja de 100 milhões o capital de empréstimo movimentado pelos bancos, e sejam o lucro médio e a taxa média de lucro, respectivamente, de 2 milhões e de $20 \%$. O capital comportado pelo comércio de crédito, a fim de que possa obter o lucro médio de 2 milhões à taxa média de lucro vigente de $20 \%$, é dada pela aplicação da fórmula acima:

$$
C_{c r}=\frac{2}{0,2}=10 \text { milhões }
$$

Ou seja, é de 10 milhões o capital máximo que pode ser aplicado no comércio de crédito a fim de que a taxa de lucro obtida não seja inferior à taxa média de $20 \%$.

Esta solução dá destaque à diferença entre os dois segmentos do capital bancário e aponta a contradição existente entre ambos, baseada na contradição entre as suas respectivas funções: o segmento de comércio de dinheiro tem seus limites estabelecidos pela estrutura e dimensão dos capitais industriais e comerciais, enquanto o segmento de comércio de crédito depende das dimensões do capital de empréstimo da economia, que não são limitadas diretamente pelo processo de reprodução. Isto está de acordo com a conclusão de Marx, de que a acumulação de capital de empréstimo é dotada de certa autonomia em relação ao capital produtivo e no longo prazo expande-se à frente deste, por diversas razões objetivas que aponta (OCIII/2, cap. 32). No curto prazo, no ciclo de negócios, a acumulação real e a produtiva tendem a evoluir em direções opostas (Ibidem, p. 33 e passim).

Evidentemente isto não poderia ocorrer se a acumulação do capital de empréstimo dependesse diretamente do processo de reprodução. As funções de comércio de dinheiro, ao contrário, estão diretamente relacionadas ao processo de reprodução, na medida que as operações monetárias flutuam acompanhando as flutuações da atividade econômica, que estas operações apenas expressam na esfera monetária. Assim sendo, as funções de comércio de dinheiro e de crédito só podem ser executadas por capitais de naturezas diferentes, embora umbilicalmente ligados pelo fato de que o comércio de crédito apoia-se na função de guarda das reservas líquidas dos capitalistas, desempenhada pelo capital de comércio de dinheiro.

\footnotetext{
${ }^{47} \mathrm{O}$ processo é formalmente idêntico ao da formação do capital fictício (OCIII/2, p. 10-11).
} 


\subsubsection{Determinação da Dimensão e do Lucro do Capital Bancário}

Com base na exposição precedente, em que se consolidou em um bloco as concepções de Marx sobre a natureza do capital e do lucro bancários, completadas pelas contribuições de Hilferding, pode-se formular as equações que representam as determinações teóricas do capital e do lucro bancários, incorporando já a concepção acabada da taxa média de lucro geral, tal como Marx a formulou.

Como já exposto, o capital bancário, representado na equação (7), é um ente econômico híbrido, que combina duas funções econômicas - e consequentemente dois capitais - de naturezas diferentes. O capital de comércio de dinheiro - como autonomização do capital aplicado pelo próprio capital industrial na realização das operações meramente técnicas decorrentes da circulação monetária - complementado pelo capital de comércio de mercadorias, na realização da circulação da sua forma final D', tem sua magnitude determinada pela magnitude e demais características da circulação monetária dos capitais industrial e comercial ${ }^{48}$.

Na medida que as condições gerais de funcionamento do comércio de dinheiro são dadas, a sua magnitude é determinada como uma proporção definida do capital social global, conforme (8). A magnitude do capital de comércio de crédito, por outro lado, é determinada da forma que se acabou de expor e representada em (12). Substituindo (12) e (8) em (7) obtém-se

$$
C_{b}=\delta C+\frac{l_{c r}}{\bar{l}^{\prime}}
$$

Observe-se a distinção essencial entre os capitais de comércio de dinheiro e de crédito, respectivamente. O lucro do capital de comércio de dinheiro, na qualidade de integrante do capital mercantil, depende das magnitudes de $\overline{l_{g}^{\prime}}$ e do capital investido no comércio de dinheiro. O comércio de crédito, ao contrário, é comércio de capital portador de juros. O rendimento do capital portador de juros é o juro, não o lucro médio, embora seja, na aparência, convertido contabilmente em lucro médio sobre o capital bancário investido, através da capitalização, à taxa média de lucro, dos juros líquidos obtidos, invertendo assim a sequência do processo real.

Que Marx concebe o problema deste modo demonstra-se pelo fato de que o juro obtido pelo capital portador de juros é uma das duas partes em que se divide o lucro médio: lucro do empresário e juro. Ou seja, o lucro do capital de comércio de crédito pressupõe a prévia formação da taxa média de lucro geral e do lucro médio. Isto significa que o capital

\footnotetext{
$48 \mathrm{O}$ capital comercial faz parte da estrutura da circulação e sua magnitude é também determinada pelas características do capital industrial, do qual é uma extensão. "Com o capital bancário [para Hilferding corresponde ao capital de comércio de crédito] ocorre uma coisa completamente diferente do que acontece com o capital industrial, mas também diferente do que acontece com o capital comercial e com o capital de comércio de dinheiro. Nestas esferas, o dimensionamento do capital é dado tecnicamente, determinado pelas condições objetivas do processo de produção e de circulação" (HILFERDING, 1985, p. 172, acréscimos próprios).
} 
investido no comércio de crédito não se confunde com o capital de comércio de dinheiro, embora ambos se combinem, na prática, constituindo o capital bancário. Ambos os capitais podem, portanto, ser separados analiticamente. Dá-se, neste caso, mais ou menos o mesmo que com o capital comercial, ao qual frequentemente estão associadas operações próprias da produção das mercadorias, que são, no entanto, excluídas na análise teórica.

O lucro médio do capital bancário consiste na soma dos lucros médios obtidos pelos capitais de comércio de dinheiro e de comércio de crédito que o constituem, e pode ser assim representado:

$$
\bar{l}_{c b}=\bar{l}_{c d}+\bar{l}_{c r}
$$

Os lucros médios dos capitais de comércio de dinheiro e de crédito são dados, respectivamente, pelas fórmulas (9) e (11). Substituindo-as em (13) obtém-se:

$$
\bar{l}_{c b}=\overline{l_{g}^{\prime}} \cdot C_{c d}+\left[j_{r}-\left(j_{p}+c c\right)\right]
$$

fórmula que explicita de forma coerente a determinação do lucro bancário total, composto pelas duas partes, proporcionadas pelos dois segmentos funcionais do capital bancário.

\section{Conclusões}

As principais contribuições deste artigo podem ser formuladas do modo que segue. Propôs-se explicitar a distinção fundamental, apontada explicitamente por Marx, mas geralmente esquecida ou não explicitada, entre a taxa média de lucro industrial $\left(\overline{l_{i}^{\prime}}\right)$ e a taxa média de lucro geral $\left(\overline{l_{g}^{\prime}}\right)$.

1. Desenvolveu-se uma representação formal do conceito definitivo da taxa média de lucro - a taxa média de lucro geral -, tal como formulado por Marx, que relaciona a mais-valia total à soma dos capitais industrial e comercial, e não somente ao primeiro, e que inclui todos os fatores essenciais à formação da taxa média de lucro. Também se demonstrou e formalizou a influência da rotação do capital sobre a taxa média de lucro.

2. Mostrou-se que a omissão dos efeitos, sobre a taxa média de lucro, tanto da rotação do capital variável quanto da participação do capital comercial, são lacunas que não podem deixar de afetar a correta interpretação dos fenômenos da economia. Mesmo nos casos em que tais fatores sejam considerados, a falta de formalização constitui fonte de confusão que pode e deve ser evitada.

3. Procurou-se identificar os argumentos de Marx que justificam a exclusão do capital de comércio de dinheiro - ao contrário do que Marx atribui ao capital comercial da determinação da taxa média de lucro geral. Isto exigiu uma exploração 
minuciosa da seção IV d'OCIII e da sua conexão com a seção V, na qual Marx analisa extensamente o capital portador de juros.

4. Demonstrou-se a distinção de natureza e de funções dos segmentos de comércio de dinheiro e de crédito, que compõem o capital bancário, e expôs-se os processos de determinação do capital investido, da taxa média de lucro e do lucro do capital bancário, e desenvolveu-se uma formalização dos mesmos. Através disto procurou-se mostrar que a distinção entre os capitais de comércio de dinheiro e de crédito é compatível com a determinação consolidada do lucro e do capital bancários.

\section{Referências}

GERMER, C.M. Componentes estruturais da teoria do dinheiro no capitalismo. Revista da Sociedade Brasileira de Economia Política, v. 1, n. 1, p. 106-33, 1997.

GERMER, C.M. e BELOTO, D.L. Marx e o problema dos custos de circulação como dedução da mais-valia. Revista da Sociedade Brasileira de Economia Política, v. 9, n. 18, p. 62-85, 2006.

GERMER, C.M. Receita pública e circulação monetária na teoria de Marx. Revista da Sociedade Brasileira de Economia Política, v. 11, n. 25, p. 5-31, 2009.

HILFERDING, R. O Capital Financeiro. São Paulo: Nova Cultural, 1985.

ILYENKOV, E. Dialectics of the abstract \& the concrete in Marx's Capital. Moscow: Progress Publishers, 1982. Disponível em:

https://www.marxists.org/archive/ilyenkov/works/abstract/index.htm.

ITOH, M.; LAPAVITSAS, C. Political economy of money and finance. London: Macmillan, 1999. 301p.

JAFFEE, D.M. Credit rationing. NEWMAN, P.; MILGATE, M. and EATWELL, J. (Eds.). The New Palgrave Dictionary of Money and Finance. Vol. 1, London: Macmillan, 1994, p. 539-541.

MARX, K. Theorien über den Mehrwert [TMV, 1a. parte]). In: MARX, K. Zur Kritik der Politischen Ökonomie (Manuskript 1861/63). Text - Teil 2. Berlin: Dietz, 1977, p. 329-668, (MEGA, II/3.2.)

MARX, K. Zur Kritik der Politischen Ökonomie (Manuskript 1861/63). Text - Teil 5. Berlin: Dietz, 1980. (MEGA, II/3.5.)

MARX, K. Das Kapital: Kritik der politischen ökonomie, Band III. Frankfurt: Ullstein Materialien, 1980. 
MARX, K. Zur Kritik der Politischen Ökonomie. In: MARX, K. Ökonomische Manuskripte und Schriften 1858/61. Text. Berlin: Dietz, p. 95-245, 1980. (MEGA, II/2).

MARX, K. O Capital: crítica da economia política, vol I/1. São Paulo: Abril Cultural, 1983.

MARX, K. O Capital: crítica da economia política, vol. II. São Paulo: Abril Cultural, 1984a.

MARX, K. O Capital: crítica da economia política, vol. III/1. São Paulo: Abril Cultural, 1984b.

MARX, K. O Capital: crítica da economia política. v. III/2. São Paulo: Abril Cultural, 1985.

MARX, K. Ökonomische Manuskripte 1863/67. Das Kapital, Drittes Buch. Berlin: Dietz, 1992.

MAYER, T.; DUESENBERRY, J.S.; ALIBER, R.Z. Moedas bancos e a economia. $4^{\mathrm{a}}$. Ed americana. Rio de Janeiro: Campus, 1993. 681 p.

MOSELEY, F. The falling rate of profit in the postwar United States Economy. London: Macmillan, 1991.

NETTO, J.P. Introdução ao estudo do método de Marx. São Paulo: Expressão Popular, 2011.

PASSARELLA, M. \& BARON, H. Capital's Pons Asinorum: the Rate of Turnover in Karl Marx's Analysis of Capitalist Valorisation. MPRA - Munich Personal RePEc Archive. MPRA Paper No. 48306, 2013. Disponível em: http://mpra.ub.unimuenchen.de/48306/.

SWEEZY, P.M. Teoria do Desenvolvimento Capitalista; Princípios de Economia Política Marxista. Rio de Janeiro: Zahar, 1976. 